\title{
"Is this War?": A Closed Border, Tense Border Standoff, Ruined Expectations and Imminent COVID-19 Disaster in the Tanzania-Uganda Borderlands
}

\author{
Switbert R. Kamazima
}

\author{
Behavioral Sciences Department, School of Public Health and Social Sciences, Muhimbili \\ University of Health and Allied Sciences, P. O. Box 65001, Dar-es-Salaam, Tanzania
}

\begin{abstract}
Coronavirus 2019 disease (COVID-19) has spread all over the world affecting 214 countries. Efforts to control the spread of the pandemic are enormous and impacting targeted populations differently. In this paper, however, I use a case of the TanzaniaUganda borderlands to demonstrate how border closure for the public health good is eroding amicable relationships that existed among the borderlanders on both sides of the border. I collected and reviewed different documents including published papers, grey literature, newspapers, media information, formal and informal reports and conducted formal and informal discussions with interested parties. Closing borders undertaken by Uganda put cross border activities and cooperation to a standstill leaving the borderlanders in puzzle. I conclude that longstanding and current perspectives of borders, borderlands and borderlanders informed COVID19 control measures imposed by Uganda and Tanzania respectively. I recommend the two governments not to allow COVID-19 to bring the borderlanders' brotherhood/sisterhood spirit and livelihoods at a standstill for a long time. Instead, let the countries make decisions and choices to live with coronavirus as they did for previous pandemics battled together in the East African region.

Key words: Tanzania-Uganda border, crossborder cooperation, Coronavirus, COVID-19, East Africa, East African Community Partner States.
\end{abstract}

\section{Introduction}

Coronavirus disease 2019 (COVID-19) is a communicable respiratory disease caused by severe acute respiratory syndrome coronavirus 2 (SARS-
CoV-2). COVID-19 was first recognized in Wuhan, China, in December 2019 [1]. By October 15,2020 (05:32 GMT) there were 38,747,126 COVID-19 reordered cases, 29,127,092 recoveriesand 1,096,888 deaths [2]. Egypt was the first country to report the first COVID-19 case in African on February 14, 2020 followed by Algeria on February 25, 2020. Lesotho was the last country on the continent to report COVID-19 case on Wednesday, May 13, 2020. By mid-May 2020, the disease had spread in all African countries. As per October 15, 2020 (05:32 GMT), the continent had recorded $1,612,737$ cases, $1,330,252$ recoveries and 38,896 deaths [2].

Kenya reported the first COVID-19 case in East Africa on March 12, 2020 followed by Rwanda (March 14, 2020), Tanzania (March 16, 2020), Uganda (March 22, 2020), Burundi (March 31, 2020) and South Sudan (April 5, 2020). Undeniably, COVID-19 is distressing all sectors of social, economic and political life in the region. To curb the noxious coronavirus spread in the region, the six East African Community (EAC) Partner States instituted containmnent measures including: adhering to strict respitatory hygiene and sanitation guidelines (washing and sanitizing hands regularly); social distacing; restricitng citizens' movement; announcing curfews and partial/full lockdown; international flights cancellation; closing learning institutions, worship places and other recreational venues; restricitng free movement of cargo across the region by road, air and water; staying at home and closing borders for the public health good. In this paper, however, I use a case of the Tanzania-Uganda borderlands to demonstrate how COVID-19 control approaches executed by Tanzanian and Ugandan governments are affecting borderlanders' livelihoods. 


\section{Materials and Methods}

I collected and reviewed different documents including media information, magazines, newspapers, formal and informal reports, published papers, grey literature and conducted formal and informal discussions with interested parties.

\section{The definition of the Tanzania- Uganda border}

The Tanzania-Uganda border stems from the Anglo-Germany delimitations of spheres of influence of November $1^{\text {st }}, 1886,1890$ and 1893 , with modifications by an Agreement of May 14, $1910[3,4]$. The $1^{\circ} 00^{\prime} \mathrm{S}$ Tanzania-Uganda terrestrial border is defined by border points (BPs) number 27 located at Kagaga on the east bank of the Kagera river as it 'crosses' the $1^{\circ} 00^{\prime} \mathrm{S}$ from Uganda into Tanzania and BP number 41located in Kashenye on the western shore of Lake Victoria in the present Missenyi district, with a few beacons in-between. The Anglo-Germany Agreement of May 14, 1910 is unspecific on the definition of the border over Lake Victoria and on Rubafu Peninsula [3].

However, the unsigned, may be due to the outbreak of World War One (WWI), draft of the AngloGermany Agreement of 1914, concluded that the whole of Rubafu Peninsula was entirety in German East Africa. Article 2 of the draft of the Agreement stipulates as follows,

Across Lake Victoria, the boundary continues to follow latitude south $1^{\circ}$, as shown in Maps 2 and 3 annexed to this Agreement to a point $1 \frac{1}{2}$ kilom. west of the coast of Rubabu [Rubafu] Peninsula, whence it runs parallel to and a distance of $1 \frac{1}{2}$ kilom. from the west coast line around the northern extremity of the peninsula until it again meets latitude south $1^{\circ}$. Thence, along that parallel of latitude... [5].

For the purpose of this paper, I identify the following borderlands along this border: Bugabo/Kasensero; Kakunyu/Nangoma Parish; Minziro/Minziro; Mutukula/Mutukula; Lukunyu/Lukunyu and Isingiro/Isingiro with comparable cross border interactions and cooperation experiences.

\section{Pre-COVID-19 cross border cooperation along the Tanzania-Uganda border}

Like other borders in Africa, the Tanzania-Uganda border divides precolonial societies the Baganda and Bahaya of Buganda and Buhaya Kingdoms respectively, into the two territories. The River Kagera was the frontier between pre-colonial Buganda and Buhaya Kingdoms. According to [6] the two colonial governments (Germans and British) did not introduce border control systems along the borderline. However, the outbreak of sleeping sickness in Uganda in 1980s attracted the Germany government to control people's movement across the border to limit the diseases from spreading into Tanganyika. Nonetheless, the border controls imposed were not effective enough to limit cross-border movements of people, goods and animals.

Following Germany's defeat in WWI, the League of Nations formed the Mandate for East Africa that divided Germany East Africa into Tanganyika under the British and Rwanda-Urundi under the Belgians in 1922. Acquiring Tanganyika made the British dream of creating the British Empire in East African became somehow true. The British government did not perceive Tanganyika-Uganda and Tanganyika-Kenya borders threats, which suggests that both formal and informal border crossing and cooperation persisted and increased in the present Tanzania, Uganda and Kenya. The Germans and later the British, introduced forced coffee production on commercial scale, forced and unpaid labor, cash economy and taxes on indigenous societies in East Africa. To meet increased labor demand in the region, the colonialists introduced policies that facilitated direct or private recruitment of labor to work on coffee and banana plantations, mines, industries and factories from Rwanda, Burundi and designated labor reserves in the British East Africa.

The British were eager to maximize profits; hence, they did not put controls over border crossing practices in the Empire. In 1927, however, the Medical Department in Uganda singled out the Banyarwanda (the Rwandese) as " dirty and diseased'... [and] 'disseminators of disease' ... spreading sleeping sickness" [7]. To curb the spread of the disease, the British introduced control measures along the Tanganyika-Uganda and Uganda-Rwanda borders. In 1929, the Labor Commission established a special camp at the Kyaka Ferry (on the Kagera river) "where Banyarwanda [were] medically examined and those with minor ailments [were] detained and treated, while more seriously debilitated individuals [were] returned back across the borders" [7]. Immigrants who passed the 'tests' were registered and allowed to proceed into British East Africa. However, given the open nature of the border, the immigrants, 
individually, families or groups, crossed the border at different points they knew [7-9]. Generally, cross border relations and cooperation along the Tanzania-Uganda border remained friendly with only a few border controls to stop the spread of human and animal diseases.

Tanganyika gained independence from Britain on December 9, 1961, Uganda on October 9, 1962 and Kenya on December 12, 1963. The new governments did not perceive borders as sources of conflict but the demarcations of the end of one territory and the beginning of the other. Instead, the independent Tanganyikan, Kenyan and Ugandan governments had imperative social, political and economic plans to accomplish for national development. The Tanganyika/Tanzania government, for example, identified ignorance, poverty, diseases and colonialism and its discontents key internal and external enemies; not the borders. Fighting internal enemies, pioneering Pan Africanism, spearheading liberation movement on the continent and beyond and the creation of the East African Community (EAC) became fundamental to the Tanganyikan/Tanzanian government.

In the spirit of Pan Africanism, Tanganyikan/Tanzanian borders remained open to freedom fighters and liberation heroes irrespective of their countries of origin. Majority of the freedom fighters and liberation heroes used Tanganyikan/Tanzanian identities to travel abroad or seek political asylum. Furthermore, the PanAfrican movement propagated for the rejection of colonial borders that divide Africa and its people for the creation of a United Africa. The Tanganyika/Tanzania political elite and the citizens alike, therefore, did not perceive borders sources of conflict [8,9]. In addition, the independent East African governments had to abide to the Organization of African Unity (OAU)'s resolution AHG/Res.16(1) adopted at the Cairo Summit in July 1964. The resolution requires all African states to respect the borders existing on their achievement of national independence.

In January 1971, Idd Amin overthrew the Uganda People's Congress (UPC)-led government. Ideological differences between Nyerere's Tanzania and Amin's Uganda led to conflicts between the two countries and ended up in the Kagera or Uganda Liberation War of 1978-1979. Since Amin's defeat and the liberation of Uganda in April 1979, both governments have accused each other for trespassing into the other's territory, establishing military posts close to the border or in the buffer zone, destroying the border beacons/BPs or failing to control pastoralists' movements across the border.

However, the border disagreements were resolved following the demarcation of the border in 2003 [10]. Since then, amicable relationships have existed between the borderlanders; between the borderlanders and their immediate authorities and between Tanzania and Uganda.Scholars [8-13] indicate that formal and informal social, economic and political cross border cooperation and interaction have been part and parcel of the borderlanders' livelihoods and wellbeing. In their view, such relationships and cooperation initiative are disrupted by misunderstandings between adjoining nation state governments $[8,11,14]$.

In 2017, the Tanzanian president and his counterpart, the Uganda President, opened a \$12 million [15,16] One Border Stop Point at Mutukula, which was meant to facilitate trade, the movement of people, and improving security; shorten the clearance time at the border crossing points and reduce logistic costs [17]. Of recent, a Kampala (Uganda)-based firm has started constructing a Mutukula Regional Market, which, among other objectives,

Aims at introducing a unique and multispecialty market, one of its kind in the East African region. The market will enhance regional cooperation, with the facilities being shared among all the traders, investors and manufacturers in the Eastern African region. It is designed to create an enabling environment for increased trade flow among partner states. With its location at the heart of East Africa, it is positioned at the intersection of the major trade routes in the region and thus able to act as a central point for intraEastern Africa trade. The regional market aims at connecting and uniting vendors in Uganda, Kenya, Tanzania, Rwanda, Burundi, Southern Sudan and Western part of Democratic Republic of Congo [18].

\section{COVID-19 hits East Africa: Tanzania's and Uganda's responses to the pandemic}

To mitigate COVID-19 spread in the region, individual Partner State governments instituted uncoordinated containmnent measures including: adhering to strict respitatory hygiene and sanitation guidelines (washing and sanitizing hands regularly); social distancing; closing learning 
institutions and other recreational venues; restricitng citizens' movement, curfews and partial/full lockdown; international flights cancellation; restricitng free movement of cargo across the region by air, road and water and closing borders for the public health good.

\subsection{Uganda's response to COVID-19}

According to $[19,20]$, Uganda begun taking measures against the deadly disease before confirmation of any COVID-19-related case or death. Uganda recorded the first COVID-19 on March 22, 2020 and by June 2020, almost all regions in the country had reported COVID-19 cases [21]. On 18 March, the government suspended, with immediate effect, all public gatherings (weddings, schools, places of worship, rallies pubs, music shows, weekly open markets and cultural meetings) for 32 days. All arrivals (foreigners and Ugandans returning home) were required to be put on mandatory 14 days quarantine at government designated hotels in Entebbe. However, quarantined persons had to foot hotel costs. On March 25, the government banned public transport operations national wide and stopped all passengers coming into Uganda by air, land or water. This order not only "affected in-coming planes, buses, taxis or boats but also prohibited from entry pedestrians trekking on foot from Uganda's neighbors in East Africa" [22]. This border crossing restriction implied that borderlanders were not allowed to cross the border from either side for whatever reason.

On March 30, the Ugandan President declared a nationwide curfew from $7 \mathrm{pm}$ to $6: 30 \mathrm{am}$, which would run for 14 days to prevent the spread of the disease. Effective from April 1, 2020, the country was under a total lockdown, other than essential workers such as medical personnel, all other persons were required to stay at home for 14 days and conform to imposed curfew and lockdown. These conditions were to be reviewed after expiry of 14 days. On April 23, 11 Tanzania trucker drivers who entered Uganda from Tanzania via the main One Stop Border Point (OSBP), Mutukula, tested positive for COVI-19 that made Ugandan authorities to blame Tanzania for not announcing lockdown [23], compelling the Minister for Health (Uganda) to declare, "All truck drivers arriving via Mutukula point of entry will be tested for COVID19 and results given within 45 minutes ... If you [truckers] are found positive, you cannot proceed with your journey ... if you're negative, you are released" [24].
ISSN 2455-6378

Following the alleged escape of a Tanzanian who tested COVID-19 positive in Kasensero, Ugandan police and military deployed marine unit forces and increased patrols at Kasensero on Lake Victoria in the Rakai border district and along the terrestrial border (Kakunyu to Isingiro) with Tanzania to stop Tanzanians from infiltrating into Uganda through the porous border to avoid the importation of the novel coronavirus [25].

On Friday, May 15, the Ugandan government tested 1,838 samples form truck drivers of whom 43 tested positive to the virus: 17 Ugandans, 14 Kenyans, five Tanzanians, two Burundians, four Eritreans and one of unknown nationality [25]. Records indicated the truck drivers were from Mutukula (on the border with Tanzania), Malaba (on the border with Kenya) and Elegu (on the border with South Sudan) border points.

To achieve successful testing of all track drivers arriving via Mutukula, the Ministry of Health (Uganda) commissioned a Port Health COVID-19 laboratory at this OSBP in April and deployed 20 more health workers (topping to 30) [18]. The laboratory is equipment with two GeneXpert machines capable of processing 64 COVID-19 samples per hour [26]. As the number of Tanzanian truckdrivers testing positive to COVID-19 spiked, the Uganda authorities intensified border surveillance by deploying prison officers, police and the military mainly along the Tanzania-Uganda border (from Kasensero southwards to Isingiro) to control people from crisscrossing the border from either side [27].

In early June, 2020, the Ugandan government eased the lockdown. Public transport services were allowed to resume under strict conditions of operators following procedures imposed to prevent the spread of coronavirus: wearing face masks, social distancing, limiting the number of passengers, checking body temperatures, hand sanitizing and recording passenger details to contact them if anybody on board tests positive [28]. However, public transport services remained restricted in the border districts and private vehicles allowed to operate with special permit from the LC1 authorities. Ugandan officials 'feared' people from neighboring countries, from Tanzania in particular, could sneak across the border, jump on buses increasing the possibly of spreading coronavirus in Uganda. The boda-boda (motorcycle) operators throughout the country were allowed to carry only cargo; not passengers. By late August, Uganda had imposed a $\$ 65$ coronavirus testing charge for volunteers and arrivals including truck drivers. This requirement sparked heated 
protests among truckers arriving from Tanzania demanding COVID-19 testing should be for free as per the EAC guidelines during CIVID-19 pandemic. As a revenge, the truckers blocked the border gate to stop their counterparts from entering Tanzania that attracted diplomatic level interventions [20].

\subsection{Tanzania's response to COVID-19}

Tanzania reported the first COVID-19 case on March 16, 2020. The government hastily closed learning institutions, banned activities and events that could result into crowding (sports, rallies and cultural events like weddings). However, the government never imposed curfew, lockdown or close the borders. Rather, Tanzania kept its air, land and water borders open with no official restrictions on internal movement among administrative districts/regions or across borders; including the Tanzania-Uganda border. International flights continued until April 12, 2020 long after its neighbors, Uganda and Kenya, for example, had suspended theirs, and then reopened on May 18, 2020 [29]. The Tanzanians, therefore, continued with their usual activities and business while adhering to all health guidelines from the government via the Ministry of Health, Community Development, Gender, Elderly and Children (MoHCDGEC) intended to combat the spread of the noxious coronavirus including good respiratory hygiene; social distancing and frequent hand washing with running water and soap or sanitizing [20].

\section{Implications of governments' COVID-19 control strategies on the Tanzania-Uganda borderlanders' livelihoods}

Indeed, COVID-19 control measures taken by the Tanzania and Uganda governments have highly impacted the amicable and coexistence relationships between the Tanzania-Uganda borderlanders. On the one hand, Uganda's decision to close the border, impose curfew and lockdown disrupted social, economic and political peace that existed between the borderlanders; between the borderlanders and their immediate authorities and between Tanzania and Uganda nation states. Similarly, closing border for the public health good and mandatory testing for COVID-19 among the truckdrivers have disrupted the free movement of people, goods and services in the region and are eroding amicable relationships that previously existed among the truck drivers; between communities along the transit routes/interregional highways and the truck drivers; between the truckdrivers and the borderlanders; between the truck drivers and border authorities; and somehow between adjoining EAC Partner States [20].

Following the border closure for the public health good, the borderlanders ceased enjoying previously accessed services on each side of the border: health (modern, African and spiritual healing), trade, family visits, education, entertainment and religious. For example, for good reasons, the borderlanders have been accessing education and health services on either side of the border [12], opportunities that have been gridlocked under the COVID-19 fear! Yet, Uganda's plead to its citizens to avoid contacts with the foreigners coming in its territory, the Tanzanians in particular, claimed could be the reservoirs and supperspreaders of coronavirus; further instilled hatred among the Ugandan borderlanders over their counterparts [20].

In addition, Uganda's decree that truck drivers carrying essential goods from different countries in the East African region entering Uganda via Mutukula border crossing point may also be carrying coronavirus and transmitting COVID-19, should undergo mandatory screening for COVID19 and their en route movements and behaviors be closely monitored and controlled, fueled horror among the Ugandan borderlanders. The ailing managed mandatory COVID-19 screening among the truckers resulted into overcrowding of truckers at Mutukula (on the Tanzania side), which fired more hatred among Ugandan borderlanders over their Tanzanian neighbors [20]. Furthermore, Uganda's deployment of police and military force to control the porous border further limited opportunities that borderlanders previously enjoyed thus, impacting exercising their deep-rooted relations along the 'artificial' border.

On the other hand, Tanzania decided to keep its borders open with these justifications: 1) Wholly heartedly, the Tanzania President noted that he did not close the borders to safeguard the "lifeline for landlocked countries (particularly Uganda, Rwanda, the DRC, Zambia and somehow Zimbabwe) in the region; 2) The Deputy Minister for Health clarified that "When you go for a total lockdown it means some will instead die of hunger" [29]; and 3) the Minister for Foreign Affairs and East Africa Cooperation added, "Coronavirus is dangerous ... but lack of essential services such as food, fuel and medical supplies to land-locked countries could be more damaging" $[20,30]$, put the borderlanders in a puzzle. The borderlanders on the Tanzania side could not 
comprehend why Uganda went on a total lockdown for a long period!

Likewise, the Ugandans on the other side of the border 'failed' to understand why Tanzania was not taking stern measures (closing the border and imposing curfew and lockdown) to curb the spread of the deadly coronavirus as their government, the EAC, the Africa Center for Disease Control and Prevention (Africa CDC) and the World Health Organization recommended. Some Ugandan borderlanders, the elite in particular, perceived Tanzania violating international directives of COVID-19 control and should be held responsible for all consequences of its loose measures against COVID-19 [20]. Moreover, the Tanzania-Uganda borderlanders on the Uganda side could not comprehend why they were restricted from visiting their families and accessing services in Tanzania and vice versa! In fact, all activities across the border came to a standstill impacting all sectors of the borderlanders' livelihoods.

\section{Discussion}

Ostensibly, Tanzania's and Uganda's unpreparedness to fight the disease as neighbor countries and member states of the East African Community (EAC) bloc, led to ungraceful measures taken by these nation states that greatly impacted the Tanzania-Uganda borderlanders' livelihoods [20]. COVID-19 period has rekindled the different contexts and processes through which the borderlanders (both permanent and temporary ones) and the political elite understand, construct and attach meanings and functions to the borders that serve to include and exclude as well.

On the one hand, Uganda mimicked measures taken in the developed world, where the longstanding perspectives conceptualize borders as tools of separation, control and limiting people's movement within their respective territories. Similarly, longstanding perspectives conceptualize borderlands as areas of contention and potential sources of political conflicts between adjoining nation states. The borderlanders, therefore, are conceptualized and labeled potential deviants conducting subversive cross-border activities including smuggling, prostitution, illegal immigration and potential carriers and spreaders of both human and animal diseases [8]. Consequently, at different times, governments put borders, borderlands and borderlanders under control of some sort: police patrols, watchtowers and tight immigration controls. In turn, these measures often turn "those who prefer to live in peace into enemies" [31]. From this view, Uganda's closure of the border for the public health good, imposing curfew and lockdown and deploying police and military surveillance were the best measures to protected the citizenry from coronavirus infections from their counterparts in Tanzania.

On the other hand, Tanzania's approach was informed by borderlands and borderlanders studies and theories that emerged beginning in the $1960 \mathrm{~s}$ when the border regions experienced rapid population growth and urbanization leading to complex forms of interconnectedness and interdependency among borderlanders of different demographic characteristics [32,33]. This perspective recognizes and conceptualizes borders as sources of both unity and identity and source of conflict and conflict resolutions [33]. Borders are both barriers and opportunities, uniting and dividing and as well as including and excluding. Scholars [34-36] contented that the borderlanders' efforts to solve common border problems for their survival result in complex mechanisms of formal and informal cross-border activities, which in turn, transform borders and the borderlands into living realities that need to be carefully examined. Tanzania government's decision not to impose curfew, lockdown or close the borders, keeping its air, land and water borders open with no official restrictions followed its leaders', the President in particular, understanding of the complex connectedness and interdependency that have roots in the history of the region and the continent at large.

Certainly, the Ugandan government could not fully limit peoples' cross-border movements along the parous terrestrial border with numerous unofficial crossing points or panya routes some of which are known to the borderlanders themselves! Unquestionably, though with difficulties, some cross-border activities continued despite the tight control measures imposed on the Tanzania-Uganda border.

\section{Conclusion and Recommendations}

Indeed, border closing for the public health good is not heathy to borderlanders in the African context especially where same communities live on both sides of the border. The Tanzania-Uganda borderlanders, for example, have experienced peaceful and conflicting interaction patterns among the borderlands, the borderlands and their states and between adjacent nation-states. It is only the political misunderstandings between neighboring states' political elite that disrupt borderlanders' connectedness and interdependency $[8,11,14]$. Certainly, COVID-19 is a life-threatening pandemic but should not be an excuse to disrupt longtime and historically-rooted amicable relationships and connectedness that have existed 
in the Tanzania-Uganda borderlands, thus separating the borderlanders and turning them into enemies. I recommend, as the two countries have successfully fought other pandemics together, including HIV and AIDS and Ebola, they should not allow COVID-19 to bring the borderlanders' brotherhood/sisterhood spirit and livelihoods at a standstill for a long time. Instead, let the countries' governments make decisions and choices to live with coronavirus as they did for previous pandemics battled together in the East African region.

\section{Acknowledgements}

The author acknowledges colleagues at the Muhimbili University of Health and Allied Sciences (MUHAS) for reading and commenting on earlier versions of this paper.

\section{References}

[1] Rothan, H. A. and Byrareddy, S. N. The epidemiology and pathogenesis of coronavirus disease (COVID-19) outbreak. Journal of autoimmunity. 109:102433. (2020). https://www.sciencedirect.com/science/article /pii/S0896841120300469 Accessed on June 24, 2020.

[2] Worldometer. COVID-19 Coronavirus Pandemic. (2020). Available at: https://www.worldometers.info/coronavirus/ Accessed on October 15, 2020.

[3] McEwen, A. C. 1971. International Boundaries of East Africa. Oxford. At the Clarendon Press.

[4] Brownlie, I. African Boundaries. A Legal and Diplomatic Encyclopedia. Barkeley. University of California Press. (1979).

[5] Delmée-Radcliffe, C. 1905. "Surveys and studies in Uganda." The Geographical Journal.

26(5https://www.worldometers.info/coronavir us/\#countries):481- 497; 616-632.

[6] Hydén, Goran. TANU YAJENGA NCHI. Political development in Rural Tanzania. Lund Political studies 8. Lund. BerlingskaBoktrytckerit. (1968).

[7] Lyons, M. Foreign Bodies: The History of Labour Migration as a Threat to Public Health in Uganda. In Nunget, P and Asiwaju, A. I. (eds). African Boundaries. Barriers, Conduits and Opportunities. London. pp. 131-144. (1996).

[8] Kamazima, S. R. Borders, Boundaries, Peoples, and States: A Comparative Analysis of PostIndependence Tanzania-Uganda Border
ISSN 2455-6378

Regions.Ph. D. dissertation. University of Minnesota. U.S.A. (2003).

[9] Kamazima S. R. Towards the understanding of citizenship problems shaking contemporary Tanzania and strategies to evade similar dilemmas in the future. IJASRM 3(1): 16-29. (2018a).

[10] Mutumba, R. Uganda, TZ surveyors demarcate boundaries. New Vision. August 29. (2003). Available at: https://www.newvision.co.ug/news/1261391/ uganda-tz-surveyors-demarcate-boundaries Accessed on September 4, 2020.

[11] Kamazima, S. R. Panorama of National Identification Registration in Kagera Region, Tanzania: A Case of Rubale Division, Bukoba Rural Border District. BAOJ HIV. 4: 02. (2018d).

[12] Kamazima, S. R. and Ngowi, A. F. Reasons why citizens utilize healthcare services across borders in Africa: qualitative findings from the Tanzania-Uganda borderlands. IJIRD. 7(6):240-250. (2018).

[13] Kamazima, S. R., Ngowi, A. F., Mosha, I. H. and Metta, E. Healthcare Providers' Perceptions of Cross-Border Healthcare Services Utilization: A Qualitative Inquiry in the Tanzania-Uganda Borderlands. BAOJ HIV. 4:033. (2018).

[14] Kamazima, S. R. Fifty years of the TanzaniaUganda $1^{\circ} 00^{\prime} \mathrm{S}$ terrestrial border peace mediation: an insider-outsider's perspective. IJARSM.2018. 3(8):1-12. (2018c).

[15] Business News. Presidents officially open upgraded \$12m Mutukula post. November 10. (2017). Available at: https://www.256businessnews.com/presidents -officially-open-upgraded-12m-mutukulapost/ Accessed On September 3, 2020.

[16] The Independent. Museveni and Magufuli launch Mutukula One Stop Border Post. Business News. November 9. (2017). Available at: https://www.independent.co.ug/musevenimagufuli-launch-mutukula-one-stop-borderpost/Accessed on August 19, 2020.

[17] Sabiiti, M. Mutukula One-Stop border post to ease trade between Tanzania, Uganda. November 9. (2017). Available at: https://www.newvision.co.ug/news/1465383/ mutukula-stop-border-post-ease-tradetanzania-uganda Accessed on August 9, 2020.

[18] Musasizi, A. Mutukula to get regional market. Daily Monitor. October 16. (2019). Available at:

https://www.monitor.co.ug/News/National/M utukula-to-get-regional-market/688334- 
5313622-wuhv5a/index.html Accessed on August 9, 2020.

[19] Wikipedia. 2020a. Coronavirus disease 2019. Available at:https://en.wikipedia.org/wiki/Coronavirus_ disease_2019Accessed on June 6, 2020.

[20] Kamazima, S. R., Kazaura, M. and Kakoko, D. C. V. From Hospitality to Hostility: Border Crossing Experiences among Unsung Heroes on the Wheel in COVID-19-Hit East Africa. IJASRM. 5(9):143-157. ISSN 2455-6378. (2020).

[21] World Health Organization (WHO). Uganda to win or lose COVID-19 war in communities. June 17. (2020a). Available at: https://www.who.int/news-room/featurestories/detail/uganda-to-win-or-lose-covid-19war-in-communities Accessed on September 3, 2020.

[22] Muhangi, K. Uganda's COVID-19 fight: Defying the odds to contain a global pandemic. (2020). Available at: https://www.newvision.co.ug/news/1518398/ uganda-covid-19-fight-defying-odds-containglobal-pandemic Accessed on June 8, 2020.

[23] Tugume, J. 11 cargo transporters test positive for COVID-19. New Vision. April 24. (2020). Available at: https://www.newvision.co.ug/new_vision/new s/1518217/cargo-transporters-test-positivecovid-19 Accessed on May 20, 2020.

[24] The Citizen Reporter. Tanzania: Arusha Regional Commissioner Now Turns the Heat On Kenyan Drivers Over COVID-19 Tests. The Citizen. Dar es Salaam. May 20. (2020a). Available at: https://allafrica.com/stories/202005200916.ht $\mathrm{ml}$ Accessed on September 3, 2020.

[25] Xinhua. Uganda beefs up security at common border with Tanzania amid COVID-19 pandemic. (2020). Available at: http://www.xinhuanet.com/english/202004/30/c_139021586.htm Accessed on September 4, 2020.

[26] World Health Organization (WHO). Uganda commissions Port Health COVID-19 laboratory at the main Uganda-Tanzania border point. (2020b). Available at: https://www.afro.who.int/news/ugandacommissions-port-health-covid-19laboratory-main-uganda-tanzania-borderpoint Accessed on May 20, 2020.

[27] Dispatch. Ugandans using trucks to flout transport ban, hampering efforts to stem
ISSN 2455-6378

COVID-19 spread. May 11. (2020a). Available at: https://www.dispatch.ug/2020/05/11/ugandan s-using-trucks-to-flout-transport-banhampering-efforts-to-stem-covid-19-spread/ Accessed on May 20, 2020.

[28] Agiresaasi, A. Public transport resumes in Uganda. (2020). Available at: https://globalpressjournal.com/africa/uganda/ public-transport-resumes-uganda/ Accessed on September 3, 2020.

[29] Kell, F. Tanzania Evades COVID-19 Lockdown, but Restrictions Persist. Chatham House. (2020). https://www.chathamhouse.org/expert/comme nt/tanzania-evades-covid-19-lockdownrestrictions-persist Accessed on June 8, 2020.

[30] Domasa, S. Tanzania: Govt Clears Up Border Saga. Daily News. Dar-es-Salaam. May 14. (2020). Available at: https://allafrica.com/stories/202005140573.ht $\underline{\mathrm{ml}}$ Accessed on August 13, 2020.

[31] Andeson, M. "The Frontiers of Europe." In Anderson, M. and Bort, E. (eds.). Boundaries and Identities: The Eastern European Union. Edinburgh. Edinburgh University Press. (1996).

[32] Hansen, N. Border Region Development and Cooperation: Western Europe and US-Mexico Borderlands in Comparative Perspective. In Martinez, O. J. (ed.). Across Boundaries. Transborder Interaction in Comparative perspective. Center for Inter-American and Border Studies. Texas Western Press. pp. 3144. (1986).

[33] Donnan, H. and Wilson, T. M. Borders: Frontiers of Identity, Nation and State. Oxford Berg. (1999).

[34] Sloan, J. W. and West, J. P. Community Integration and Policies Among Elites in Two Border Cities, Los dos Laredo. Journal of International Studies and World Affairs. 18(4):451-474. (1976).

[35] Sloan, J. W. and West, J. P. The Role of Informal Policy Making in US-Mexico Border Cities. Social Science Quarterly. 58(2):270-282. (1977).

[36] Asiwaju, A. I. Solving Problems Along African Boundaries: The Nigeria-Benin Case Since 1889, In Martinez, O. J (ed.) Across Boundaries. Transborder Interaction in Comparative Perspective. Texas Western Press. (1986). 